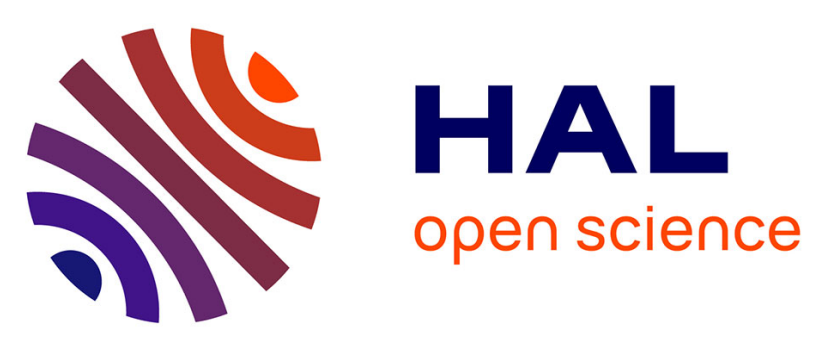

\title{
The Burundian army's trajectory to professionalization and depoliticization, and back again
}

\author{
Nina Wilén, Gérard Birantamije, David Ambrosetti
}

\section{To cite this version:}

Nina Wilén, Gérard Birantamije, David Ambrosetti. The Burundian army's trajectory to professionalization and depoliticization, and back again. Journal of Eastern African Studies, 2017, 12 (1), pp.120-135. 10.1080/17531055.2017.1418173 . halshs-01951938

\section{HAL Id: halshs-01951938 \\ https://shs.hal.science/halshs-01951938}

Submitted on 11 Dec 2018

HAL is a multi-disciplinary open access archive for the deposit and dissemination of scientific research documents, whether they are published or not. The documents may come from teaching and research institutions in France or abroad, or from public or private research centers.
L'archive ouverte pluridisciplinaire HAL, est destinée au dépôt et à la diffusion de documents scientifiques de niveau recherche, publiés ou non, émanant des établissements d'enseignement et de recherche français ou étrangers, des laboratoires publics ou privés. 


\section{The Burundian army's trajectory to professionalization and} depoliticization, and back again

Nina Wilén

Department of Political Science, Université Libre de Bruxelles

Gérard Birantamije*

GRAPAX, Université Saint-Louis-Bruxelles

David Ambrosetti

CNRS (LAM, Bordeaux / CFEE, Addis Ababa)

\footnotetext{
*Nina Wilén: nina.wilen@ulb.ac.be

*Gérard Birantamije: birager@yahoo.fr

*David Ambrosetti: d.ambrosetti@sciencespobordeaux.fr
} 
How can post-conflict militaries with a history of politicized oppression and exclusion achieve professionalization? National armies face a number of challenges at the end of internal conflicts, including, but not limited to, structural reforms ${ }^{1}$, integration of new actors, such as former rebels and/or underrepresented groups ${ }^{2}$, and most often a restrained budget from a war-tired state ${ }^{3}$. On top of these more practical challenges (which nevertheless imply a new type of mentality), the army may also face an identity crisis as its earlier links with the governing regime have been cut off, creating a new, politically independent institution. But to what extent can a post-conflict army, previously a central actor in a civil war, adhere to international standards for a professional army, including depoliticization from domestic politics?

In this article we examine the Burundian army's trajectory from a perspective of longue durée, studying its role in and for the state since the proclamation of the Burundian Republic in 1966 through the civil war in the beginning of the 1990's to the current political crisis, which started in 2015 with the President's decision to go for a contested third term. The case of Burundi is interesting, because contrary to other states where rebels have become rulers after taking the complete control of the state apparatus ${ }^{4}$, in Burundi, the former rebels have accessed power following detailed power-sharing arrangements with the former government, including the loyalist army. One of the aims of this detailed power-sharing mechanism, and arguably its major achievement, has been the creation of an integrated and depoliticized national defence force.

In this article, we examine how this experiment developed by consulting primarily historical and contemporary documents and academic articles, complementing the findings with over 50 interviews conducted with Burundian soldiers between 2011-2014 by the three authors. The aim of the article is to increase understanding of how, and to what extent, the Burundian army has managed to professionalize after the end of the civil war in the beginning of the 
2000 's, in spite of its violent and exclusionary history. In doing this, we aim to identify and analyse the conditions, processes and actors that have influenced the Burundian army's trajectory toward a limited professionalization.

We argue that the Burundian army has managed to professionalize and depoliticize to a limited extent (and with important constraints) following the end of the civil war due to three factors: 1) an important pre-war heritage of a technically and functionally professional, yet politicized army; 2) a favourable domestic political climate where the army no longer needs to play a political role but can take on the role of the domestic peacemaker ${ }^{5}$; 3) significant external training and support related to peacekeeping deployment and Security Sector Reform (SSR). This professionalization has however partly been reversed during the recent crisis starting in 2015 , showing the fragility of a post-conflict professionalization where ties between old and new officers and political actors are revoked again.

As such, the article enters into the literature of military professionalization, an area which in recent years has been given new attention for several reasons, including, but not limited to, the military's new roles due to emerging security threats such as terrorism ${ }^{6}$, the large amount of new troop contributing states to peace operations ${ }^{7}$, the increased focus on peacekeepers' human rights abuses ${ }^{8}$, but also the many new human rights courses and civil-military educations ${ }^{9}$ which the military is subject to in various settings. Yet professionalization of the military is important to study, not only for its impact on peacekeeping missions, but also for its domestic role. This is especially so for post-conflict armies, which have been important actors during previous conflicts and which require new identities and new roles to function in a society recovering from conflict. This article contributes to this relatively new and underresearched topic of how post-conflict militaries can professionalize and find new identities in the aftermath of civil wars ${ }^{10}$. 
The article is structured as follows. Firstly, we analyse and interpret the meaning of military professionalization through a literature review of military professionalization, both examining the literature from before the end of the Cold War and looking into the relatively recent SSR literature. We also attempt to clarify the relationship between professionalization and politicization in this section. In a second part we examine the Burundian army's political role since the instauration of the Burundian republic in 1966, and its relation to professionalization. Third, we look at the army's new political roles as a domestic peacemaker and an international peacekeeper after the end of the civil war and examine how these roles have opened up new opportunities for professionalization. Finally, we look at the effects of the current political crisis in Burundi on the army in terms of professionalization and attempt to draw wider conclusions from the case of Burundi.

\section{Unpacking the relation between Military Professionalization and Politicisation}

Military professionalization is a concept, which has been employed to capture both a necessary and a desirable modernization of the armed forces, yet surprisingly little is published on the details of such a process. Early analyses of professionalism view it as a type of normative value system or a form of 'moral community' based on occupational membership ${ }^{11}$. Huntington's identification of three essential elements of military professionalism could fit into such an understanding of the concept: expertise, responsibility and corporateness ${ }^{12}$. Expertise in the sense that the professional military has the right knowledge and skills to exercise the profession, responsibility, as the client of the military profession is society - individually and/or collectively, and corporateness as the members of the military share a sense of organic unity which separates them from laymen ${ }^{13}$. Indeed, laymen must place their trust in professionals and professionals need to be worthy of that 
trust, to maintain confidentiality and not exploit their expertise for evil purposes. In return, professionals are rewarded with authority, privileged rewards and higher status ${ }^{14}$. The above characteristics are related to the integration of a military ethos, which can be characterised as a blend of both modern managerial qualities and traditional values such as bravery, obedience, discipline and dedication to public service ${ }^{15}$.

A dedication to public service can take different forms however, and researchers have debated to what extent the military should be involved in domestic politics, if at all. Huntington defined military professionalism as the complete subordination of the military to an objective civilian authority. In other words, the armed forces are politically sterile and neutral, with no other significant social or political role ${ }^{16}$. This notion of civilian authority over military command has remained a crucial component of military professionalism over the years, although it has been subject to academic debate. Janowitz, for example, argued that technological progress and new missions led to an inevitably more political role for the professional soldier, and that civil-military relations resulted in the soldier being integrated with civil values ${ }^{17}$, whereas Abrahamsson went even further and contended that the professionalized military was a politicized, active interest group, with the need for a system of institutional control mechanisms ${ }^{18}$. Yet in spite of its contested nature, the idea of military subordination to civil control has remained an essential part of common understanding of military professionalism, even though, as Cottey at al. note, in most cases, the focus on the degree of separateness of military and civilian sectors often has been misplaced ${ }^{19}$ and at times exaggerated.

However, for post-conflict armies, the concern with depoliticization remains relevant, given that politicization, questionable loyalties, abuses of power, corruption and lack of accountability to civilian political authorities ${ }^{20}$, are likely to affect not only the military's role 
in society in general, but also the larger peacebuilding process. The depoliticization element has been given new impetus following the end of the Cold War, when the understanding of the relationship between the military and society changed. It was no longer enough that the military should be subordinate to civilian control, but this control should assume the characteristics of democratic management ${ }^{21}$. Consequently, a conceptual and normative shift in the content of many of the military courses being presented to African countries by foreign governments could be seen at the end of the Cold $\mathrm{War}^{22}$. The programmes increasingly began to emphasize the role of stable civil-military relations and previously marginalised actors, such as civilian defence officials, parliamentarians and civil society representatives were integrated in the programmes ${ }^{23}$. Professionalism began to be used as a discourse to promote and facilitate particular occupational changes by politicians and military advisers ${ }^{24}$. This has taken its most visible expression in the emergence of the concept of Security Sector Reform (SSR).

The Security Sector Reform (SSR) literature often refers to 'professional military' as part of the objective with $\mathrm{SSR}^{25}$. It prescribes norms and rules for the military institution in general which should deliver security effectively and efficiently, consistent with democratic norms and the principles of democratic governance, rule of law, and human rights in a transparent system $^{26}$. The security forces should be professional, subordinate and accountable to civilian authorities and fulfil their mandate in accordance with international and constitutional law ${ }^{27}$. The principle of military subordination and depoliticization remains thus a crucial component of today's ideal of professionalization in the SSR literature, yet these concepts are embedded in a larger normative context where the civil-military relations should be democratic and transparent ${ }^{28}$.

There is also a managerial side to the discourse of professionalism, inherent in the SSR language of an efficient and effective military. Evetts describes it like this: 
Professionalism in the armed forces includes budgetary constraints and financial cut-backs; strict control of armaments and equipment costs; a decrease in numbers of personnel which at the same time is a more highly trained and disciplined work force; an increase in organizational features in the military which include an increase in bureaucracy, managerialism, accountability and audit; an enlarged and expanded role which includes global policeman alongside defensive and offensive combatant functions; and an international, as well as a national, identity to make more efficient organizational use of scarce defence resources ${ }^{29}$.

An additional aspect of professionalization is therefore related to the military's technical capacity and refers to the introduction of modern military equipment, established procedures for recruitment and promotions and advanced training ${ }^{30}$. Complete professionalization refers thus to both an integration of a particular military ethos defined as a group of shared values, including the acceptance of subordination under civilian authorities, and a modernisation and restructuration of the armed forces to make it capable, efficient and functional ${ }^{31}$.

\section{A Historical Glance at the Burundian Army's Professionalization}

The Burundian military has been a factor of political tension and violence since Burundi's independence in 1962 and particularly since the military putsch in 1966, which led to the creation of the First Burundian Republic. Military officers were heavily involved in politics during this time, which opposed the traditional aristocracy (the Ganwa), the dominating Tutsi clans called "Banyaruguru" (literally 'from the North), and the pro-Hutu militants inspired by the "Social Revolution" in Rwanda in 1959-1962 32 . Once Burundi became independent, Burundian officers originating from the Bururi province in the South of the country, who were close to the political party Uprona (Union et progrès national), acquired important political roles in the country. In 1966, they staged a military coup, which conferred the political power to a military-led institution, the Conseil National Révolutionnaire, where 
officers from the Bururi province rapidly became over-represented. In this new Uprona-led regime, Captain Michel Micombero (originating from the Bururi province) became the head of the state. His two successors, Jean-Baptiste Bagaza and Pierre Buyoya, who also used military coups to attain power under the umbrella of the Uprona, were also from Bururi. The military leadership was thus intertwined with the political civilian elites within the sole political party: Uprona ${ }^{33}$.

In its quest for order, legitimacy and political survival, the military regime violently deterred any attempts of Rwanda-inspired revolutions. This culminated in the "selective genocide" in 1972 when tens of thousands of Hutu civilians were killed by the army and Hutu militaries were expelled from the military institution ${ }^{34}$. As such, the army became known as the "monoethnic Tutsi army". The military's role was key to the political survival of the minority Tutsi regime $^{35}$ and was thus far from a neutral and independent institution. The oppression of Hutus and the ethnic tension that followed lasted more than 15 years, with several incidents of mass killings ${ }^{36}$.

Yet, while the military remained heavily politicized, it was a professional army in the sense that the army members shared a professional identity, associated with common experiences, understandings and expertise, shared ways of perceiving problems and their possible solutions ${ }^{37}$. This common identity was reproduced through a shared educational background and professional training - both at home and abroad. A tangible proof of this was Burundi's creation of a military academy in 1973 for its officers, the Institut supérieur des cadres militaires (ISCAM). The older officers $(50+)$ who we have interviewed referred to their diplomas and qualifications acquired at the ISCAM as institutionalised steps in their careers, and they were also given a unique opportunity to graduate in sciences, law or economics, at 
the Université de Bujumbura. Many of them had also trained in foreign military academies (Belgium, Greece, France, USSR, US, UK) during the 1970s and 1980s.

However, the continuation of, not only a strongly politicized, but also ethnicized army, became impossible to maintain for the Burundian regime, and under Pierre Buyoya's presidency in the 1980's and early 1990's, initiatives were taken to introduce democracy and make the army more representative of the society it was to protect, mainly by opening up recruitment for ISCAM to Hutu candidates. These were the first attempts to democratize the country and depoliticize the army, yet while they did lead to the first democratic election of a Hutu president, Melchior Ndadaye, in June 1993, hardliners within the army were resisting the changes and the new president was assassinated only three months later by elements of the Burundian $\operatorname{army}^{38}$. The assassination became the ignition for a bloody civil war, which lasted a decade, and in which the army maintained a central role. By the end of the civil war, the demand for a new, integrated and representative army stood out as the most crucial factor in the Burundian quest for peace ${ }^{39}$.

The highly sought-after military reform was achieved a few years after new peace talks. Once again in power after his second coup (1996), Pierre Buyoya engaged in political discussions with the pro-Hutu political opposition in order to end the conflict ${ }^{40}$. While the signing of the Arusha agreement in 2000 was the official symbol for the end of the conflict, the signing of the Accord technique des forces in November 2003 between the transitional government dominated by members of the Uprona and Tutsi military elites on the one hand, and the main pro-Hutu rebel group, the CNDD-FDD, on the other, allowed the creation of a new national army in 2004, the Force de defense nationale (FDN), composed mainly of the former two enemies (the loyalist Forces Armées Burundaises (FAB) and the rebel CNDD-FDD). The 
Burundian army, as the main political actor in the country, thus showed that it was willing to accept a reduction in its political influence in order to play the role as the new, neutral peacemaker. In particular the ex-FAB's roles in ending the Burundian conflict by stepping back from their privileged status within the state, was systematically raised as key to the peace process by the officers we interviewed. This development, which ended the longstanding oppression of Hutus meant an upsurge in popularity of the Hutu-dominated party CNDD-FDD, which subsequently won the 2005 elections that brought Pierre Nkurunziza to power ${ }^{41}$.

\section{The army's new roles as a domestic peacemaker and an international peacekeeper}

The combination of a domestic environment in which the army could step back from its earlier political role, together with new incentives to professionalize through internationally sponsored SSR- courses and pre-deployment formations for international peace operations gave the FDN the possibility to depoliticize and submerge into all aspects of professionalization, normative, managerial and technical. In particular, its new, integrated status gave way to a more balanced and neutral role.

The new FDN reflected the army's central role in the domestic peacebuilding process with a rather sophisticated balance in the official positions between the former army and the former rebels, but also between different communities and regions of the country ${ }^{42}$. Several parallel processes have had positive influence for the army's integration process at large, which has been considered as a success story by academics and practitioners alike ${ }^{43}$, including halted forced demobilisation and the implementation of international programs, allowing large financial and technical influx. The integration of former rebels in the army also removed the mono-ethnic characteristic from the institution and made a politically neutral army more feasible, especially given political parties' strong ethnic bases ${ }^{44}$. These quotas between ex- 
FAB and ex-rebels were also present within the Burundian contingents in Somalia, as an institutional mark of the Burundian army's expertise in power-sharing mechanisms but also as a symbol for the overall peace process in Burundi ${ }^{45}$.

\section{(i) From the domestic role of a military ruler to the one of peacemaker}

The new ethnically representative FDN became the subject for more intensive technical professionalization. Foreign assistance and demands from multilateral peacekeeping forces brought new specialities in the Burundian contingents, the national training centres, and within the état-major itself (on principles of peacekeeping, international humanitarian law, human rights, medical support, high tech equipment, civil-military relations, counterterrorism, illicit trafficking, HIV/AIDS, etc. $)^{46}$. International courses on human rights and civilian protection in relation to peace operations testified recognition of a new type of civilmilitary relations, whereby the soldier integrated civil values - in line with how the SSR literature describes the security forces as part of, yet simultaneously serving, the public. Militaries of different backgrounds were sent to attend such courses both locally and at regional peacekeeping centres. The regional peacekeeping centres, such as the Kofi Annan International Peacekeeping Centre in Ghana or the International Peace Support Training Centre in Kenya, where a variety of courses related to peacekeeping are available, have constituted an important opportunity, particularly for the former rebels to compensate their lack of formal education and get necessary qualifications ${ }^{47}$.

The peacekeeping experience itself, which primarily has taken place in a hostile environment in Somalia, has offered an opportunity to put these new skills into practice in extreme operational conditions. The fact that Burundian soldiers trained the Somalian army and guarded the presidential palace in Mogadishu appears to be proof of their technical reliability ${ }^{48}$. The long-lasting deployment to international peace operations has thus given the 
Burundian troops some international recognition. The Burundian army, which up until its first deployment mainly had been turned inwards to deal with domestic problems, now turned outwards, working with international counterparts in new settings.

\section{(ii) Professional and financial opportunities for the individual soldier}

The army's new role as a 'peacekeeping army' also implied new opportunities for the individual soldier. Participation to international peacekeeping generates important incomes. These remunerations have eased many of the tensions related to the integration between rebels and former government forces, and permitted individuals to look forward to a financially more stable future ${ }^{49}$. Waiting for one's turn to be deployed in peace operations abroad has thus become an additional reason for staying in the army. Another important aspect related to peacekeeping experience concerns the soldiers' professional expectations. Many of our respondents envisioned an international civilian career in the future, as they could work along and build rich networks among international peace and security practitioners ${ }^{50}$. Courses, certificates and diplomas acquired during peacekeeping predeployment training were seen as important steps on the way to an international career. However, some interviewees also revealed the flop side of such expectations. Burundian officers (specialised in International Humanitarian Law, for example) who had expected to pursue a career in the field of peace and security after their first deployment to Somalia realised how rare these opportunities were, particularly when lacking a political network.

External incentives and domestic possibilities aligned thus in the aftermath of the civil war for a complete professionalization of the Burundian army. Yet, the professionalization faced a number of tests resulting from a continuously fragile and tense domestic environment, including a staged coup attempt $t^{51}$, political assassinations by members of the army ${ }^{52}$ and distribution of arms to the militias ${ }^{53}$ amongst others. However, while the army relatively 
successfully has managed to divert such threats to its professionalization, the latest challenge in the shape of the Burundian President's decision to run for a contested third term has provoked more visible cracks in the army's professionalization, and opened rooms for repoliticization.

\section{The Burundian Integrated Army Faces a Disintegrated Political Deal: New Calls for}

\section{Re-Politicization}

The most serious challenge to the Burundian army's professionalization came in April 2015 in the shape of the President's bid for a third term considered by opponents (and many external observers) to be unconstitutional. The army remained neutral at the beginning of a period with massive demonstrations whereas the police showed its pro-government stance in violent crackdowns on demonstrators ${ }^{54}$. At some point the military was also seen protecting civilians from police violence ${ }^{55}$. This could indicate that the military had integrated civilian values from its different educations related to SSR and peacekeeping. It also showed how the police force alongside the SNR (Service National de Renseignements), the intelligence service, was the most politicized security forces in Burundi, clearly supporting the regime. In other words, the strong politicization of the police force and the SNR may have permitted a certain depoliticization of the army, as it made the latter a less indispensable tool in the hands of the regime. This division of tasks thus gave the army the possibility to remain outside of politics. However, with the recent wave of violent political confrontations, more empirical data are needed to tell if the political part played by SNR and the police still encourage a 
depoliticization of the army. One hypothesis is that the SNR's ultra-politicization can have induced a politicization of the army as the two institutions are known to exchange officers ${ }^{56}$.

More recent events have also put the military's professionalization in question. The failed coup attempt in May 2015 became the most visible sign of division within the army, where parts of the army remained loyal to the government, whereas a small faction attempted to overthrow the President. Following the coup, Nkurunziza violated an unspoken rule whereby the Defense Minister and the Chief of Staff should represent different ethno-political components, i.e. a Tutsi from ex-FAB and a Hutu from ex-rebels (called PMPA, partis et mouvements politiques armés), by replacing the Minister of Defence (an ex-FAB), with a civilian, Emmanuel Ntahomvukiye from his own party, CNDD-FDD ${ }^{57}$. Despite the fact that the new minister is a Tutsi, public opinion and especially ex-FAB militaries considered this move to be an attempt of politicization of the armed forces for two reasons. First, as a civilian, he may have difficulties keeping control of the armed forces. Second, as he is from the ruling party CNDD-FDD, he is considered biased in favour of the ex-rebels. In short, while the army has faced multiple challenges to its coherence and unity during the last two years, on surface, it has remained united and silent.

Yet, reports of desertions, kidnappings and targeted killings have plagued the military since then. In particular, ethnicized rhetoric from both government and opposition has been translated into ethnic patterns of violence, whereby Tutsi minority-heavy districts of Bujumbura have been targeted by security forces ${ }^{58}$. The military itself has not been excluded from this pattern. Tutsi officers have reportedly been disproportionately targeted by forced replacements by Hutu colleagues, underscoring rumours of divisions along ethnic lines within the army ${ }^{59}$ and police raids supposedly systematically targeting former FAB soldiers' houses while avoiding the ex-PMPA's soldiers. Opposing positions between the Defence Minister (former FAB) and the Army's Chief of Staff (ex-PMPA) with regard to the army's 
role during the protests in April and May 2015, with the Defence Minister justifying the army's involvement as a safeguard for the Arusha Accords ${ }^{60}$ and the Chief of Staff calling on the army to be loyal to the Burundian authorities, made the cracks in the army more visible ${ }^{61}$.

The event on the $11^{\text {th }}$ of December in 2015 was the watershed event when it comes to mass violence in this latest crisis. As rebels attacked three military bases and 8 members of the security forces were killed, the latter responded with summary killings and sexual violence in neighbourhoods with a large number of government opponents ${ }^{62}$. Although the term 'security forces' refers to both police and army, it seems unlikely that the army was not involved in any of the violence. Especially not so as witnesses reported of nine mass graves, including one in a military camp ${ }^{63}$. The current political crisis has therefore offered a window of opportunity to different actors (military actors, political actors and civil society organisations) to engage in the politicization of the army.

In the wake of the 11-12 December massacre in Bujumbura, and after international pressure, the Peace and Security Council of the AU decided to send a peace support operation to Burundi: "Mission Africaine de Prévention et de protection au Burundi" (MAPROBU). For the $\mathrm{AU}$, this unprecedented move was made to prevent another genocide on the continent ${ }^{64}$. Two days after this statement, the Burundian government organized a campaign against MAPROBU, arguing that sending a peace operation could destabilize the sovereignty of Burundi. Moreover, Burundi as a troop contributing country (TCC) was not in need of external peacekeepers on its own territory ${ }^{65}$. The government framed the opposition to the peace operation in terms that made the intervention more about the Burundian army's capacity as a military than about the political crisis, thereby withdrawing attention from the government's role. During several weekends, demonstrations were held in all provinces by the ruling party CNDD-FDD to "support the Burundian army" and resist an intervention. The 
army's peacekeeping role was central in the slogans chanted throughout towns and provinces:

"Our security forces who are peacemakers around the world, cannot commit crimes against their fellow citizens. They have been acting with efficiency against terrorists as they did in elsewhere in Somalia, Mali, and Central African Republic." 66

The ruling party's mobilization and refusal of the AU intervention underlined the possibility of re-politicizing the army.

Apart from the ruling party, civil society organizations have also participated in attempts at politicizing the army since the beginning of last crisis. One such attempt was the social media movement "bringbackoursoldiers", which asked for the return of the soldiers deployed to AMISOM in Somalia ${ }^{67}$. The movement was launched on social medias such as Twitter and Facebook $^{68}$, initially with the aim to get peacekeeping troops to come back home in order to protect the civilian population. However, as civil society was monitoring repressions by the army and the police, the aim changed to asking the UN or the AU if these soldiers (who allegedly committed crimes in their own country) were the ones needed to restore peace and stability in other states.

The case of Colonel Baratuza, spokesperson of the FDN and appointed to MINURCA in CAR (Central African Republic) as Deputy Spokesperson of the mission was symbolic from this perspective. Baratuza was repatriated to Burundi after civil society organizations contested his nomination to the UN mission based on his declarations related to the military camps attacks on 11-12 December ${ }^{69}$.This social media campagne has continued and led to the return of three majors from the $\mathrm{FDN}^{70}$. In line with this, civil society organizations have sent a letter to the UN Secretary General Ban Ki-Moon and the AU Chair, Dlamini-Zuma, asking them to send back all Burundian soldiers in peacekeeping missions so that they can protect 
their fellow citizens ${ }^{71}$, However, repatriated militaries may instead take out a revenge on the civil society organisations for robbing them of the financial opportunity that peacekeeping deployment entails. Civil society's monitoring of the army, although in line with general SSR recommendations, may therefore also run the risk of politicizing and dividing the army.

A final example of another challenge to the army's professionalization is the recent attempt by the EU to channel AMISOM allowances directly to the Burundian soldiers ${ }^{72}$, an initiative which already in February 2015, was brought up by the Burundian civil society in the form of a letter to the EU High Representative ${ }^{73}$. The objective is to bypass the Burundian government in the chain of payment as it is known to take $200 \$$ from each paycheck ${ }^{74}$. The EU's reduction in AMISOM payments by $20 \%$ in January 2016 for all troops, as well as severe delays of payments, with some troops alledgedly going without pay for over a year ${ }^{75}$, have also undoubtedly increased the pressure on the Burundian army's recent professionalisation.

\section{Conclusion}

The Burundian army today has committed several human rights abuses against opponents of the current government, which suggests that the army no longer can be considered as depoliticized. Its involvement in politics also means that its professionalization process, at least partially, has come to a stop. However, it should also be kept in mind that the army remains subordinate to the civilian authority, in spite of the fact that it no longer can be considered democratic. The fact that the army has not disintegrated completely (yet) is another factor which provokes the question of whether this is a sign of professionalization or just politicization. If the army imploded now, it would most certainly develop into a civil war. From one point of view then, a unified army saves lives. Yet, if the army maintains its 
loyalty to the current regime and continues to (in) directly support human rights abuses against its opponents, it can no longer be considered professional.

This article has evoked questions related to the relationship between an army's professionalization and (de)politicization. A quick look at the current state of affairs in subSaharan Africa today, suggests that this is a timely topic. Not only because the domestic relationships between armies and regimes in the region of the Great Lakes are intricate and complex, but also because external assistance such as pre-deployment training and SSR processes put pressure on the armies to reform and conform to international standards of professionalization. In this paper we have provided an analysis of the Burundian army's professionalization and (de) politicization during the past 15 years and highlighted some of the complexities that these processes evoke but more research into this topic is needed in order to understand more completely the challenges a post-conflict, troop contributing army stands before.

\footnotetext{
${ }^{1}$ Powell, "SSR in Burundi".

${ }^{2}$ Licklider, New armies; Wilén, "From foe to friend".

${ }^{3}$ Gupta et al., «Les insaisissables dividendes de la paix », 49-51.

${ }^{4}$ See for example Purdékova et al. 2017, "Militarisation of governance"; Lyons, "Victorious Rebels".

${ }^{5}$ Wilén et al. "Sending Peacekeepers Abroad".

${ }^{6}$ Evetts, 'Explaining the construction of professionalism'.

${ }^{7}$ Cunliffe, Legions of Peace. .

${ }^{8}$ Higate and Henry, "Engendering Insecurity"; Notar, "Peacekeepers as Perpetrators".

${ }^{9}$ Jowell, An Institutional Analysis. .

${ }^{10}$ See Beswick, "Peacekeeping, Regime Security"; Barany, "Building National Armies"; Kühnel-Larsen, Peace by Peace.

${ }^{11}$ Evetts, 'Explaining the construction of professionalism', 760.

${ }^{12}$ Huntington, "The Soldier and the State", 8.

${ }^{13}$ Ouédraogo, "Advancing Military Professionalism in Africa".

${ }^{14}$ Evetts, 'Explaining the construction of professionalism', 762.

${ }^{15}$ Danopoulos, "Military Professionalism", 505; Wolpin, "Sociopolitical Radicalism",

${ }^{16}$ Huntington, "The Soldier and the State", 80-84.

${ }^{17}$ Janowitz, M., "The Professional Soldier".

${ }^{18}$ Abrahamsson, Military Professionalization, 160.

${ }^{19}$ Cottey et al. "The Second Generation Problematic", 35.

${ }^{20}$ Simonsen, "Building 'national' armies", 584.

${ }^{21}$ Born, "Democratic Control", 153; Cottey et al. "Rethinking Democracy", 32.

${ }^{22}$ Williams, "Armed African Forces", 6.

23 Ibid.

${ }^{24}$ Evetts, 'Explaining the construction of professionalism', 767.
} 
${ }^{25}$ OECD DAC, "Enhancing the Delivery of Justice and Security"; Nathan, "Local Ownership of Security Sector Reform"; Williams, "Armed African Forces", 1-35.

${ }^{26}$ Hänggi, "Security Sector Reform"; 341; Williams, "Armed African Forces", 6.

${ }^{27}$ OECD DAC, "Enhancing the Delivery of Justice and Security"; Nathan, "Local Ownership of Security Sector Reform".

${ }^{28}$ Cottey et al. "Rethinking Democracy".

${ }^{29}$ Evetts, 'Explaining the construction of professionalism', 771.

${ }^{30}$ Kamrava, "Military Professionalization", 68.

${ }^{31}$ Ouédraogo, "Advancing Military Professionalism in Africa".

${ }^{32}$ Lemarchand, "Burundi. Ethnic Conflict and Genocide".

${ }^{33}$ Nimubona, «Analyse des représentations du pouvoir politique. Le cas du Burundi »

${ }^{34}$ Lemarchand, "Burundi. Ethnic Conflict and Genocide".

${ }^{35}$ Vandeginste, Stones Left Unturned.

${ }^{36}$ Chrétien et Mukuri (Ed.), Burundi, la fracture identitaire, 2002

${ }^{37}$ Evetts, 'Explaining the construction of professionalism', 762.

${ }^{38}$ Ntibazonkiza, Biographie du Président Ndadaye, 1996.

${ }^{39}$ Curtis, "The International Peacebuilding Paradox"., Arusha agreement for Peace and reconciliation, 2000

${ }^{40}$ Daley, "The Burundi Peace Negotiations", 333-352.

${ }^{41}$ Falch, Vers une démocratie durable au Burundi ? », 2009 : 9-10; ICG, «Elections au Burundi », $2005: 7$

42 "(The) Pretoria Protocol on Political, Defense and Security Power Sharing in Burundi", Boshoff, H., and Gasana, J.-M., "Mapping the Road to Peace in Burundi".

${ }^{43}$ Rumin, "Burundi", 91; Samii, "Perils or Promise"; Wilén, "From Foe to Friend".

${ }^{44}$ Vandeginste, "Governing ethnicity after genocide".

${ }^{45}$ Rumin, "Burundi".

${ }^{46}$ US ACOTA, for instance, program falls into the category of a typical "capacity-building" organization, as it provides extensive field- and staff-training and exercises for battalions, brigades, and multinational force headquarters personnel. Burundi has also, alongside Uganda, been chosen by the US to receive additional counter-terrorism training and equipment under section 1206 to combat Al-shabab in Somalia. In 2012, for example, Uganda and Burundi received the sum of $18,8 \$$ millions together in counter-terrorism support for deployment to Somalia. On these aspects, see Bruton and Williams, "Counterinsurgency in Somalia", 40; Serafino, "Security Assistance Reform", 7 ; Kühnel-Larsen, J., "Peace by Peace", 235.

${ }^{47}$ Flaspöler, Adding peacekeepers to the debate of critical peacebuilding », 231-246.

${ }^{48}$ AG News, Burundi/Amisom: Somalie-sécurisation de l'aéroport », 2016

${ }^{49}$ See note 4 above.

${ }^{50}$ Interviews with Burundian Officers, Military Academy, Bujumbura, March 2013.

${ }^{51}$ Cour suprême du Burundi [Burundi Supreme Court], "Arrêt nRPS.60"; Amnesty international, " Tortures ou mauvais traitement/craintes de tortures ou de mauvais traitements".

${ }^{52}$ Net Press, "Burundi-sécurité : Les dessous du dossier 'Massacres de Muyinga"'; Net press, "SécuritéJustice".

${ }^{53}$ BNUB, "Reports of alleged distribution of weapons to the Imbonerakure".

${ }^{54}$ Wilén, N, “"'Burundi Crisis: The military's central role",

${ }^{55}$ Le Monde, "Burundi : un militaire tué par un officier du renseignement".

${ }^{56} \mathrm{RFI}$, « Burundi : le président nomme un nouveau chef des services secrets », 2015.

${ }^{57}$ Journal Iwacu, "Remaniement ministériel".

58 Jones, "There are signs of renewed ethnic violence in Burundi".

${ }^{59}$ Bigirimana et al., "Des Imbonerakure sont-ils en RDC?".

${ }^{60}$ Madirisha, "La grande muette a parlé...", 14.

${ }^{61} \mathrm{AFP}$, "Manifestations : le gouvernement burundais avertit de faire intervenir l'armée".

${ }^{62}$ McCormick, "What Really Happened on Burundi's Bloody Friday".

${ }^{63}$ Amnesty International, "Burundi: Suspected Mass Graves of Victims of 11 December Violence".

${ }^{64}$ UA/CPS, "Communiqué de la $565^{\mathrm{e}}$ réunion du CPS sur la situation au Burundi".

${ }^{65}$ Mbazumutima et al., "Bujumbura s'oppose à l'envoi des troupes de l'Union africaine".

${ }^{66}$ Chorus in one of demonstrators songs.

${ }^{67}$ Ubwani, "Bring back our soldiers, Burundian activist begs".

${ }^{68}$ Turner, "Can you win a war on facebook".

${ }^{69}$ Fouchard, "Centrafrique : la mission de l'ONU ne veut pas d'un porte-parole burundais".

${ }^{70}$ Madirisha et al., "Trois hommes avertis en valent beaucoup".

${ }^{71}$ RAPRED-Girubuntu, « Payer au Gouvernement les indemnités du contingent burundais à l'AMISOM, 2017.

74 Blair, "EU takes aim where it hurts". 
${ }^{75}$ MOU "Burundi-AU".

${ }^{76}$ Williams, 'Paying for AMISOM'.

\section{Bibliography}

Abrahamsson, B., Military Professionalization and Political Power, Beverly Hills \& London: Sage Publications, 1972.

AG News, Burundi/Amisom: Somalie-Sécurisation de l'aéroport de Galmudug et du Palais présidentiel d'Adado », available at http://burundi-agnews.org/afrique/burundi-amisomsomalie-securisation-de-laeroport-de-galmudug-et-du-palais-presidentiel-dadado/, accessed, 07/09/2017.

Ambrosetti, D., "The Diplomatic Lead in the United Nations Security Council and Local Actors' Violence: The Changing Terms of a Social Position”, African Security, vol.5, n², 2012, pp. 63-87.

Amnesty international, "Burundi: Suspected Mass Graves of Victims of 11 December Violence", 28 January 2016, available at: https://www.amnesty.org/en/documents/afr16/3337/2016/en/, accessed 23 February 2016.

Anderson, D.M., and J. Fisher, Africa's New Authoritarians: Aid Securitisation and Statebuilding (Hurst: London, forthcoming 2017).

Barany, Z., "Building National Armies after Civil War: Lessons from Bosnia, El Salvador, and Lebanon", Political Science Quarterly, vol.129, n², 2014, pp.211-238.

Beswick, D., "Peacekeeping, Regime Security and 'African Solutions to African Problems': exploring motivations for Rwanda's involvement in Darfur”, Third World Quarterly, vol. 31, $\mathrm{n}^{\circ} 5,2010, \mathrm{pp} .739-754$.

Bigirimana, C., Hakizimana, D., Madirisha, E.,and Ngendakumana, P., "Des Imbonerakure sont-ils en RDC?", Journal Iwacu, available at http://www.iwacu-burundi.org/desimbonerakure-sont-ils-en-rdc/, accessed May, 19, 2014.

Blair, E. 2016. "Exclusive: EU takes aim where it hurts Burundi - peacekeeper funding."

Reuters 29 March. http://uk.reuters.com/article/uk-burundi-security-eu-exclusiveidUKKCNOWVOBR

BNUB, "Reports of alleged distribution of weapons to the Imbonerakure", 3 April 2014, pp.12.

Born, H., "Democratic Control of Armed Forces", Carforio, G. (ed.) Handbook of the Sociology of the Military, Springer, 2006, pp.151-165.

Boshoff, H., and J.-M. Gasana. "Mapping the Road to Peace in Burundi: The Pretoria Sessions." Situation Report, ISS, November 23, 2003. 
Bruton, B.E., Williams, P.D., "Counterinsurgency in Somalia: Lessons Learned from the African Union Mission in Somalia, 2007-2013, Joint Special Operations University Report, 14-5 September 2014.

Campbell, S.P., Kayobera, L., Nkurunziza, J., Independent external evaluation Peacebuilding fund projects in Burundi, March 2010.

Chrétien, J-P., Mukuri, M. (Ed.), Burundi. La fracture identitaire. Logiques de violences et certitudes "ethniques", Paris, Karthala, 2002.

Cottey, A., Edmunds, T, and A. Forster, "The Second Generation Problematic : Rethinking Democracy and Civil-Military Relations", Armed Forces \& Society, vol.29, n 1, 2002, pp.3156.

Cour suprême du Burundi, Arrêt nRPS.60 du 15 janvier 2007.

Cunliffe, P., Legions of Peace : UN peacekeepers from the Global South, Hurst Publishers : London, 2014.

Curtis, D., "The International Peacebuilding Paradox: Power Sharing and Postconflict Governance in Burundi”, African Affairs, vol.112, n446, pp. 72-91.

Daley, P., "The Burundi Peace Negotiations: An African Experience of Peace-making", Review of African Political Economy, vol.34, ${ }^{\circ} 112$, 2007, pp. 333-352.

Danopoulos, C.P., "Military Professionalism and Regime Legitimacy in Greece, 1967-1974", Political Science Quarterly, vol.98, n³, 1983, pp.485-506.

Esbjörnsson, E. "Vi som bor här har stridit för fred [We who live here, have fought for peace]." (Svenska Dagbladet, July 30, 2012). Accessed December 16, 2012. http://www.dn.se/nyheter/varlden/vi-som-bor-har-har-stridit-for-fred.

Evetts, J., "Explaining the construction of professionalism in the military: history, concepts and theories", Revue Française de Sociologie, vol. 44, n²4, 2003, pp.759-776.

Faleh, A., "Vers une démocratie durable au Burundi? Une évaluation des promesses et écueils du processus de démocratisation au Burundi”, Rapport PRIO, mai 2009.

Flaspöler, A., "Adding peacekeepers to the debate of critical peacebuilding: New insights from the perspective of peacekeeping training in Africa", Peacebuilding, Vol. 4, 2016, pp.231-246.

Gupta, S. et al., "Les insaisissables dividendes de la paix. Comment les conflits armés et terrorisme pèsent sur les résultats économiques », Finances et développement, décembre 2002, pp.49-51.

Higate, P. and M. Henry, "Engendering (In)security in Peace Support Operations", Security Dialogue, 35:481, 2004, pp. 481-498. 
Human Rights Watch, "Burundi Massacre convictions a victory", 24 October 2008, available at: http://www.refworld.org/docid/4906c7aac.html, accessed 5 October 2015.

Huntington, S., The Soldier and the State, the Belknap Press of Harvard University Press, London, Cambridge, 1957.

Hänggi, H., "Security Sector Reform" in Chetail, V ed. Post-Conflict Peacebuilding: A Lexicon, Oxford: Oxford University Press, 2009, pp. 337-349.

Iwacu, "La semaine dédiée au combattant du Cndd-Fdd", 18 November 2016, available at: http://www.iwacu-burundi.org/la-semaine-dediee-au-combattant-du-cndd-fdd/, accessed 20 December 2016.

ICG, «Elections au Burundi : Reconfiguration radicale du paysage politique », Briefing Afrique $\mathrm{n}^{\circ} 31$, Nairobi/Bruxelles, 25/8/2005

Janowitz, M., The Professional Soldier: A Social and Political Portrait, the Free Press, New York, 1960.

Janowitz, M., The Military in the Political Development of New Nations, University of Chicago Press, Chicago, 1964.

Janowitz, M., "Military Elites and the Study of War", Conflict Resolution, vol.1, n 1, 1957, pp.9-18.

Jones, C., "There are signs of renewed ethnic violence in Burundi", Monkey Cage Blog, Washington Post, 15 December 2015, available at: https://www.washingtonpost.com/news/monkey-cage/wp/2015/12/15/there-are-signs-ofrenewed-ethnic-violence-in-burundi/, accessed 23 February 2016.

Journal Iwacu, "Notre dossier Contradiction”, Iwacu n49 du 05 février 2010, pp.1-7.

Jowell, M., An Institutional Analysis of Peacekeeping Training Centres in Africa, $\mathrm{PhD}$ Thesis, unpublished, SOAS University of London, 2015.

Kamrava, M., "Military Professionalization and Civil-Military Relations in the Middle East", Political Science Quarterly, vol.115, n¹, 2000, pp.67-92.

Kühnel-Larsen, J., Peace by Peace: The Construction of National-Military Identity in PostGenocide Rwanda, PhD Thesis, unpublished, Department of Political Science, University of Copenhagen, 2014.

Le Monde, "Burundi: un militaire tué par un officier du renseignement, neuf manifestants blesses", $\quad 30 \quad$ April 2015, available at: http://www.lemonde.fr/afrique/article/2015/04/30/burundi-un-militaire-tue-par-un-officier-durenseignement-neuf-manifestants-blesses_4625973_3212.html, accessed 24 February 2016.

Lemarchand, R., Burundi: Ethnic Conflict and Genocide, Wilson Center Press et Cambridge University Press, 1995.

Licklider, R. (ed.), New Armies from Old. Merging Competing Military Forces after Civil Wars, Georgetown University Press, Washington DC, 2014. 
Lyons, T., "Victorious Rebels and Postwar Politics", Civil Wars, vol.18, n², 2016, pp.160174.

McCormick, T., "What Really Happened on Burundi's Bloody Friday", Foreign Policy, 14 December, 2016, available at: http://foreignpolicy.com/2015/12/14/what-really-happened-onburundis-bloody-friday https://matsutas.wordpress.com/2015/07/29/can-you-win-a-war-onfacebook-by-simon-turner/, accessed 23 February 2016.

Memorandum of Understanding between African Union and Burundian Government regarding troop contribution to AMISOM, 15 July 2011.

Nathan, L., "Local Ownership of Security Sector Reform: A Guide for Donors", January 2007, available

at: http://www.lse.ac.uk/internationalDevelopment/research/crisisStates/download/others/SSRRe formNathan2007.pdf, accessed 22 February 2016.

Net press, "Sécurité-Justice: Le ministre de la défense nie toute implication dans le dossier 'Assassinats de Muyinga'”, 29 janvier, 2007.

Net Press, "Burundi-sécurité: Les dessous du dossier 'Massacres de Muyinga' ", 30 janvier 2008.

Net Press, "Certaines familles des militaires et policiers refusent toujours de quitter les casernes», 31 octobre 2009.

Ngendakumana, P., "Distribution d'armes aux Imbonerakure : le gouvernement refuse une commission d'enquête internationale», Iwacu, 14-04 2014, disponible sur http://www.iwacuburundi.org/gouvernement-burundi-refuse-une-commission-enquete-internationaleimbonerakure/, consulté le 14 avril 2014.

Nimubona, J., Analyse des représentations du pouvoir politique: Le cas du Burundi, Villeneuve-d'Ascq, Presses universitaires du Septentrion, 2002.

Notar, S. A., "Peacekeepers as Perpetrators: Sexual Exploitation and Abuse of Women and Children in the Democratic Republic of the Congo", Journal of Gender, Social Policy and the Law, n² (2006), pp.413-429.

Ntibazonkiza, R., Biographie du Président Melchior Ndadaye. L'homme et son destin, Sofia, Bulgarian Helinski Committee, 1996.

OECD. 2007. Enhancing the Delivery of Justice and Security. Paris: Organisation for Economic Cooperation and Development.

Powell, K. 2007. "Security Sector Reform and the Protection of Civilians in Burundi: Accomplishments, Dilemmas and Ideas for International Engagement." CENAP/NSI Working Paper. Ottawa: The North-South Institute.

The Pretoria Protocol on Political, Defense and Security Power Sharing in Burundi 2003, available at: http://peacemaker.un.org/node/165, accessed 21 September 2017. 
Purdekova, A., Reyntjens, F. and N. Wilén, "Militarisation of governance after conflict: beyond the rebel-to-ruler frame - the case of Rwanda", Third World Quarterly, http://dx.doi.org/10.1080/01436597.2017.1369036

Ouédraogo, E., "Advancing Military Professionalism in Africa", Africa Center for Strategic Studies, Research Paper n6, Washington DC., July 2014.

RAPRED-Girubuntu, «Payer au Gouvernement les indemnités du contingent burundais à l'AMISOM, c'est financer indirectement les crimes commis au quotidien au Burundi », Lettre au Haut Représentant de l'Union pour les affaires étrangères et Politique de sécurité, Février 2017.

RFI, "Burundi: le Président nomme un nouveau chef des services secrets", available at http://www.rfi.fr/afrique/20150224-burundi-president-nomme-nouveau-chef-services-secretsetienne-ntakarutimana, last accessed 08/09/2017.

Rumin, S. "Burundi." In Disarmament, Demobilization and Reintegration and Security Sector Reform, edited by A. Bryden and V. Scheerer, 71-115. Geneva: DCAF, LIT, 2012.

Samii, C., "Perils or Promise of Ethnic Integration? Evidence from a Hard Case in Burundi", American Political Science Review, vol.107, n³, 2013, pp. 558-573.

Simonsen, S-G., 'Building 'National' Armies - Building Nations: Determinants of Success for Postintervention Integration Efforts', Armed Forces and Society, vol. 33., n 4, 2007, pp. 371-190.

Serafino, N.M., "Security Assistance Reform: 'Section 1206' Background and Issues for Congress”, Congressional Research Service Report, 8 December 2014.

Turner, S., "Can you win a war on facebook", published on Mats Utas blog, 29 July 2015, available at : https://matsutas.wordpress.com/2015/07/29/can-you-win-a-war-on-facebook-bysimon-turner/, accessed 23 September 2015.

Ubwani, Z. "Bring back our soldiers, Burundian activist begs," The Citizen, available at http://www.thecitizen.co.tz/News/Bring-back-our-soldiers--Burundian-activistbegs/1840340-3036282-format-xhtml-h6n09cz/index.html, accessed January 16, 2016.

US. Department of State. African Contingency Operations Training and Assistance (ACOTA), Program. Washington, DC: Fact Sheet. February 6, 2013. Accessed May 20, 2014. http://www. state.gov/r/pa/prs/ps/2013/02/203841.htm.

Vircoulon, T., «A l'intérieur de la crise burundaise(I) : Une armée divisée et en pertes de repères, http://blog.crisisgroup.org/africa/2015/10/02/a-linterieur-de-la-crise-burundaise-iune-armee-divisee-et-en-perte-

dereperes/?utm_campaign=shareaholic\&utm_medium=facebook\&utm_source=socialnetwork consulté le 06102015.

Vandeginste, S., Stones Left Unturned: Law and Transitional Justice in Burundi, Antwerp, Oxford, Portland, Intersentia, 2010.

Vandeginste, S., "Governing ethnicity after genocide: ethnic amnesia in Rwanda versus ethnic power-sharing in Burundi”, Journal of East African Studies, vol.8, n², 2014, pp. 263-277. 
Wilén, N., "Examining the Links between Security Sector Reform and Peacekeeping Troop Contribution in Post-Conflict States", forthcoming 2017.

Wilén, N., A "Burundi Crisis: The military's central role", Centre for Security Governance, 16 May 2015, available at: http://www.ssrresourcecentre.org/2015/05/16/burundi-crisis-themilitarys-central-role/, accessed 16 May 2015.

Wilén, N., B "From foe to friend: Military Integration after War in Burundi, Rwanda and the Congo", International Peacekeeping, vol. 23, n²1, 2015.

Wilén, N., Ambrosetti, D., Birantamije, G. A, "Sending Peacekeepers Abroad, Sharing Power at Home: Burundi in Somalia", Journal of Eastern African Studies, vol.9, n², March 2015, pp.307-325.

Wilén, N., Birantamije, G., Ambrosetti, D., "Is Burundi still a credible peacekeeper?", Monkey Cage Blog, Washington Post, 23 May 2015, available at: http://www.washingtonpost.com/blogs/monkey-cage/wp/2015/05/23/is-burundi-still-acredible-peacekeeper/, accessed 23 May 2015.

Williams, P.D., "Paying for AMISOM: Are Politics and Bureaucracy Undermining the AU's Largest Peace Operation?", International Peace Institute (IPI) Global Observatory, 11 January 2017.

Williams, R., “Armed African Forces and the Challenges of Security Sector Reform”, Journal of Security Sector Management, March 2005, pp. 1-35.

Wolpin, M.D., "Sociopolitical Radicalism and Military Professionalism in the Third World", Comparative Politics, vol.15, n², 1983, pp.203-221. 